\title{
Corrosion and contact resistance measurements of different bipolar plate material for Polymer Electrolyte Membrane Fuel Cells
}

\section{Yue Hung and Hazem Tawfik}

Institute for Research and Technology Transfer (IRTT), Farmingdale State University of New York, Farmingdale, NY 11735, USA

E-mail: hungy@farmingdale.edu E-mail: tawfikhh@farmingrdale.edu

*Corresponding author

\section{K.M. El-Khatib and Hammam El-Abd}

Chemical Engeering and Pilot Plant Departement, National Research Center, Tahrir Street, Dokki, Giza 12622, Egypt

E-mail: kamelnre@hotmail.com

E-mail: Hammamabdelrahman@yahoo.com

\begin{abstract}
Different types of commercial stainless steels (SS316, SS310 and incoloy 800), poco graphite, composite graphite, titanium carbide, zirconium carbide and carbide base coating on aluminum substrate using thermal spray technique were evaluated as metallic bipolar plate in terms of Interfacial Contact Resistance (ICR) and corrosion resistance in a solution simulating the environment of a bipolar plate in a Polymer Electrolyte Membrane Fuel Cell (PEMFC), $0.5 \mathrm{M} \mathrm{H}_{2} \mathrm{SO}_{4}$ and $200 \mathrm{ppm} \mathrm{HF}$ at room temperature. In addition, a comparison between graphite composites and carbide-based amorphous metallic coating alloy bipolar plate cost analysis. Results show that stainless steel have a high ICR and undergo corrosion in both anode and cathode due to the passive film formation. Moreover, although carbide-based alloy showed an ICR much less than composite graphite, their behaviour was not satisfactory in corrosive acidic medium.
\end{abstract}

Keywords: Polymer Electrolyte Membrane Fuel Cell; PEMFC; corrosion resistance; metallic bipolar plate; cost analysis.

Reference to this paper should be made as follows: Hung, Y., Tawfik, H., El-Khatib, K.M. and El-Abd, H. (2008) 'Corrosion and contact resistance measurements of different bipolar plate material for Polymer Electrolyte Membrane Fuel Cells', Int. J. Alternative Propulsion, Vol. 2, No. 1, pp.72-85.

Biographical notes: Yue Hung is a Technical Support Personnel in Mechanical Engineering Technology Department at Farmingdale State College 
research assitant of the Institute for Research and Technology Transfer. He has over 10 years of experience in CAD/CAM and the fields of PEM Fuel Cells.

Hazem Tawfik is a Distinguished Professor in Mechanical Engineering Technology Department at Farmingdale State College and Director of the Institute for Research and Technology Transfer (IRTT). He has more than 35 years of academic and industrial experience including fuel cell technology.

Hammam El-Abd is a Professor of Chemical Engineering and Pilot Plant Department, he has a distinctive experience for more than 41 years in the fields of fuel cells, water pollution, air pollution, pilot plant design and operation and process equipment design as well.

Kamel El-Khatib is an Associate Professor at the Chemical Engineering and Pilot Plant Department, he has a distinctive experience for more than 20 years in the fields of PEM fuel cells and metal hydride hydrogen storage.

\section{Introduction}

The Polymer Electrolyte Membrane Fuel Cell (PEMFC) is a clean energy system that can convert hydrogen and oxygen (or air) directly to electricity with water as the only chemical by-product (Steele and Heinzel, 2001). The hydrogen oxidation reaction occurs in the PEMFC anode side, while the oxygen reduction reaction occurs in the PEMFC cathode side. Since a single cell can only give an output voltage of around $0.5-0.7 \mathrm{~V}$ the cells are stacked together in series, connected by means of bipolar plates. The combination of the size of the plates (relating to the total current), coupled to the number of cells in the stack, provides the requisite power.

The bipolar plates constitute the backbone of the hydrogen fuel cell power stack, conduct current between the cells, facilitate water and thermal management through the cell, and provide conduits for the reactant gases, namely, hydrogen and oxygen. In the Polymer Electrolyte Membrane (PEM) hydrogen fuel cells design, bipolar plates are highly repeated items and therefore they must be made of material with excellent manufacturability and suitable for cost effective high volume automated production systems. Currently, graphite composites are considered the standard material for the PEM bipolar plates because of its low surface contact resistance and high corrosion resistance (Hentall et al., 1999; Mehta and Cooper, 2003). Unfortunately, graphite and graphite composites are classified as brittle and permeable to gases with poor cost effectiveness for high volume manufacturing processes relative to metals such as aluminum, stainless steel, nickel, titanium, etc. Since durability and cost represent the two main challenges hindering the fuel technology from penetrating the energy market and competing with other energy systems.

Considerable attention was recently given to metallic bipolar plates for their particular suitability to transportation applications. Metals enjoy higher mechanical strength, better durability to shocks and vibration, no permeability and much superior manufacturability and cost effectiveness in relation to carbon-based materials, namely, carbon-carbon and carbon-polymer composites. However, the main handicap of metals is the lack of ability to combat corrosion in the harsh acidic and humid environment inside the PEM fuel cell without forming oxidants, passive layers and metal ions that 
cause considerable power degradation. Accordingly, considerable attempts are being made using noble metals (Wind et al., 2002) non-coated metals like stainless steel, titanium and Nickel (Davies et al., 2000; Li et al., 2003; Wang, Sweikart and Turner, 2003; Wang and Turner, 2004; Hermann, Chaudhuri and Spagnol, 2005; Iversen, 2006) and various coated materials with nitride, carbide and different material-based alloys (Borup and Vanderborgh, 1995; Woodman et al., 1999; Lee, Huang and Chen, 2003; Brady et al., 2004; Li et al., 2004; Wang et al., 2004a,b; Jayaraj et al., 2005; Nikam and Reddy, 2005; Gamboa et al., 2006; Tian, Sun and Wang, 2006) to improve metals' corrosion resistance without sacrificing the surface contact resistance and maintaining cost effectiveness.

In this work, we evaluate different types of commercial stainless steels (SS316, SS310 and incoloy 800), composite graphite and carbide-base coating on aluminum substrate using thermal spray technique as metallic bipolar plate in terms of Interfacial Contact Resistance (ICR) and corrosion resistance in a solution simulating the environment of a bipolar plate in a PEMFC, $0.5 \mathrm{M} \mathrm{H}_{2} \mathrm{SO}_{4}$ and $200 \mathrm{ppm} \mathrm{HF}$ at room temperature. In addition, a comparison between graphite composites and carbide-based amorphous metallic coating alloy bipolar plate cost analysis.

\section{Experimental}

\subsection{Materials and electrochemistry}

Many different materials was selected to be tested as a bipolar material for PEMFC like poco graphite, composite graphite, bulk SS316, bulk SS310, incoloy 800, titanium carbide, zirconium carbide and carbide base thermal spray coating on aluminum. All electrochemical experiments were conducted in deaerated $0.5 \mathrm{M} \mathrm{H}_{2} \mathrm{SO}_{4}+200 \mathrm{ppm} \mathrm{HF}$ solution at room temperature. A conventional three-electrode system was used for the electrochemical measurements, with a platinum sheet as the counter electrode and a Saturated Calomel Electrode (SCE) as the reference electrode. Unless otherwise specified, all electrode potentials will be referenced to the SCE. A Gamry potentiostat interfaced with a computer controlled the electrochemical experiments. Dynamic polarisation was used to compare the general corrosion resistance of the different material. In these tests, samples were stabilised at the Open Circuit Potential (OCP) for 5 min, and then the potential was swept from the OCP towards anodic potentials with a scanning rate of $1 \mathrm{mV} \mathrm{sec}^{-1}$.

\subsection{Interfacial Contact Resistance}

The experimental setup in Figure 1 was utilised to measure the ICR between the Gas Diffusion Layer (GDL) and various bipolar plate materials. The purpose was to select bipolar plate material with low ICR and high corrosion resistance. The system consisted of Faraday Cage that encompassed a heavy base with a hydraulic press and a pressure gauge. Two copper plates were mounted on the two jaws of the press to apply various pressures ranging from 25 to $300 \mathrm{~N} \mathrm{~cm}^{2}$ on the samples positioned between these jaws. The four-probe technique used was a high accuracy Agilent Technologies system to measure voltage and current in nanovolts and microamps, respectively. The Faraday Cage was installed to protect the system from any external electrical charge that may 
cause disturbance to the system and jeopardise its accuracy. The shunt resistance $(R)$ shown in Figure 1 was $1 \% \pm 0.5 \Omega$ accuracy with $1 \mathrm{~A}$ applied across this resistance. The voltage $V 2$ is measured and the total resistance across the test section $R 1$ and $R 2$ are measured to calculate the ICR between the bipolar plate sample material and the GDL from the following equation:

$$
\mathrm{ICR}=\frac{R 2-R 1}{2}
$$

where $R 1$ is resistance of the GDL without the sample material and $R 2$ is resistance of the GDL with the sample martial.

Figure 1 Interfacial Contact Resistance setup (see online version for colours)
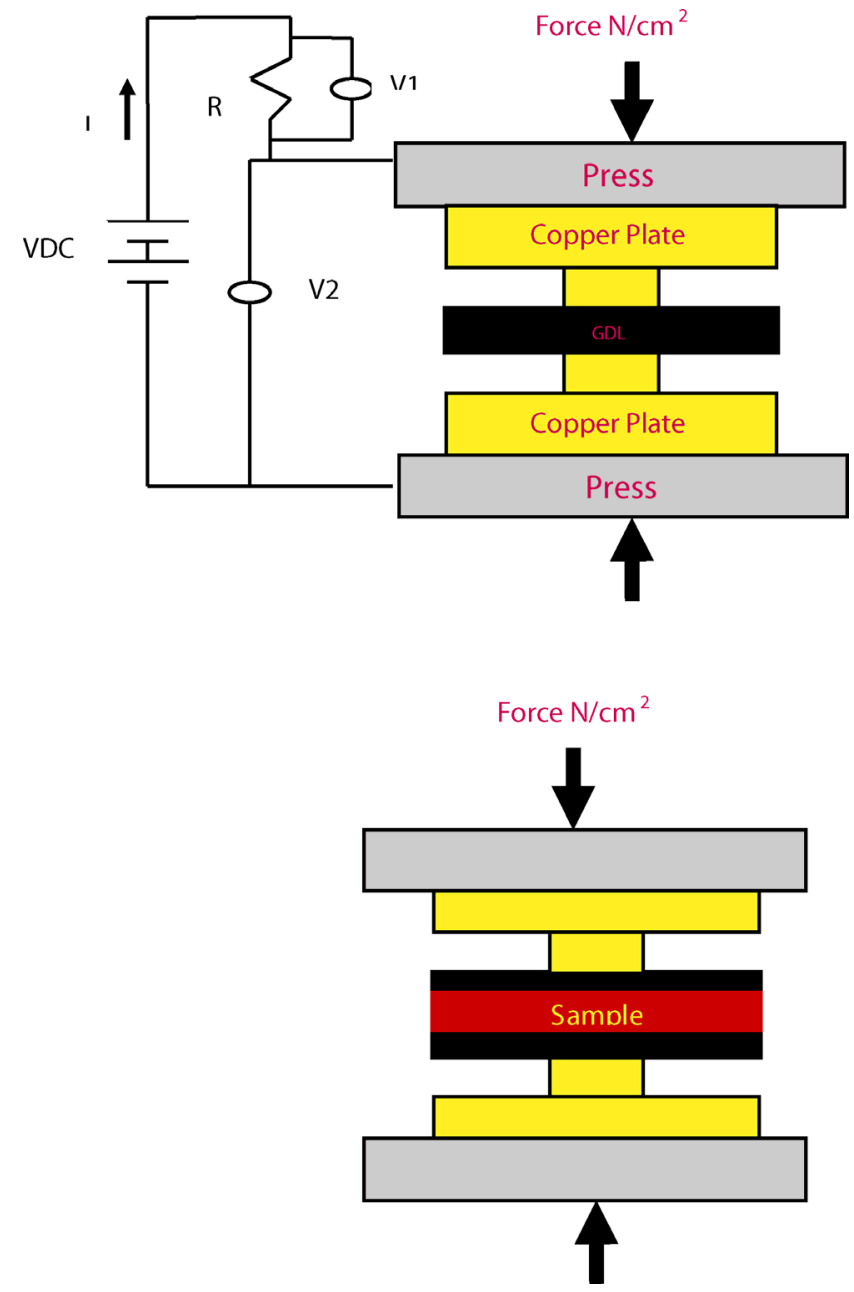


\section{Results and discussion}

\subsection{Interfacial Contact Resistance}

The ICR with the fresh samples and carbon paper was determined for different compaction forces, ranging from 25 to $300 \mathrm{~N} \mathrm{~cm}^{2}$. Figure 2 shows the ICR at different compacting force for the studied materials. It can be seen that the performance of poco graphite has a lower ICR value comparing to the other samples, while the most of the samples has the same general behaviour as that of poco graphite, but with slightly higher ICR values. The exception is SS316 and zerconium carbide, which is higher than the other samples. The ICR results give the performance order of: poco graphite $>$ thermally-sprayed carbide base $>$ composite graphite $>$ titanium carbide $>$ incoloy $800>$ SS310 $>$ zirconium carbide $>$ SS316. Thermal spray carbide base is still an excellent candidate material for PEMFC as metal bipolar plates since the differences in ICR values are rather small.

Figure 3 shows the results at the typical compaction force of a single cell $\left(200 \mathrm{~N} \mathrm{~cm}^{-2}\right.$ ) (Davies et al., 2000) evidencing for a higher stainless steel ICR value than that of commonly used graphite. The result of the iron-based samples agrees with the trend observed by Davies et al. (2000) and Wang, Sweikart and Turner (2003) for the same stainless steel specimens and attributed to the thickness of a passive film of chromium, iron and nickel oxides formed on the steel surface that inhibits the electrical conductivity. In particular, the decrease of ICR was attributed to an increase in Cr content in the alloy and in the surface film Wang, Sweikart and Turner (2003). While the lower contact resistance of the thermal-sprayed carbide base was attributed to the lower thickness of the passive film of chromium content of the carbide base alloy.

\subsection{Electrochemical measurements}

Figures 4 and 5 show the potentiodynamic polarisation curves for the studied materials for bipolar plate in the simulated environment of the fuel cell shows the corrosion current densities of the poco graphite, composite graphite, thermally-sprayed carbide base coating, titanium carbide, zirconium carbide, SS310, SS316 and incoloy 800 were about $3.86,0.419,54.7,10.7,2.98,0.612,4.8$ and $2.12 \mu \mathrm{A} \mathrm{cm}{ }^{2}$, respectively, as shown in Figure 6. Composite graphite and SS310 fulfil the Department of Energy (DOE) corrosion current target value, while poco graphite, zirconium carbide, SS316 and incoloy 800 have a corrosion current densities value slightly higher than the DOE target value. Titanium carbide showed one order of magnitude higher than the DOE target value while thermally-sprayed carbide base showed two order of magnitude more than the DOE target value. Iron-based alloy and thermally-sprayed carbide base showed a passive layer at different corrosion current densities and corrosion potential. The corrosion current densities and passive current densities results give the performance order of SS310< incoloy $800<$ SS316<thermally-sprayed carbide base, while the pitting potentials were almost has a constant value 1 Variable Stream Control Engine Voltage versus Saturated Calomel Electrode (Vsce). The non-metallic alloy not show any pitting behaviour with increasing the polarisation potential 
Figure 2 Contact resistance of different bipolar plate material (see online version for colours)

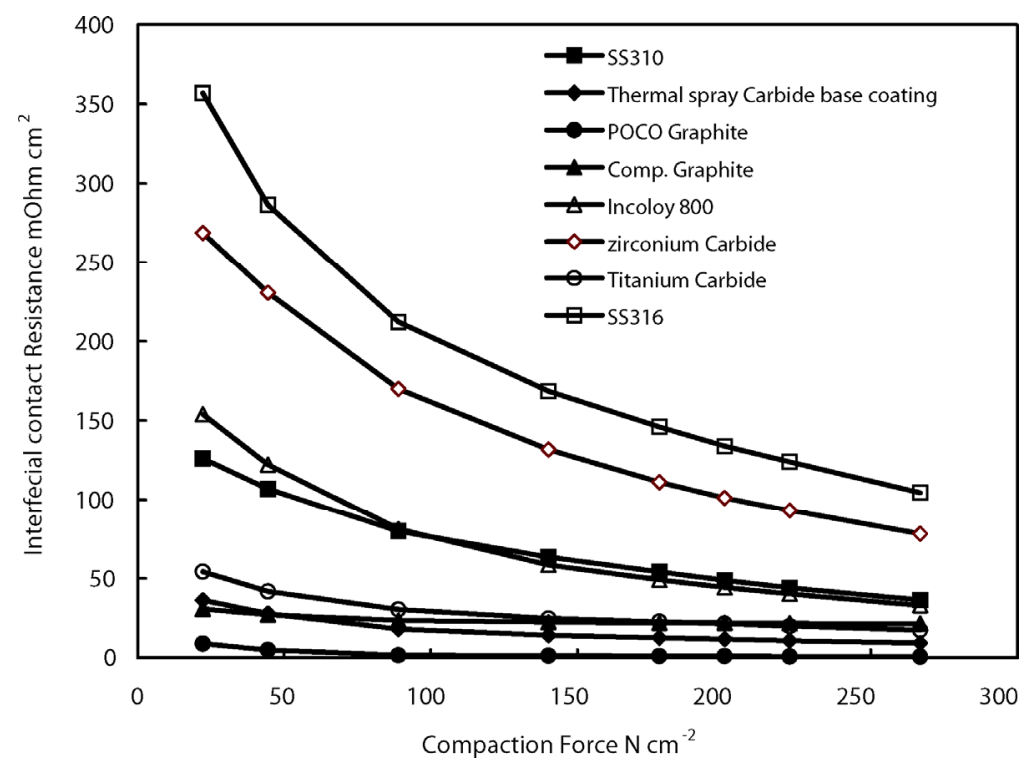

Figure 3 Contact resistance of different bipolar plate at $200 \mathrm{~N} \mathrm{~cm}^{-2}$ compacting force

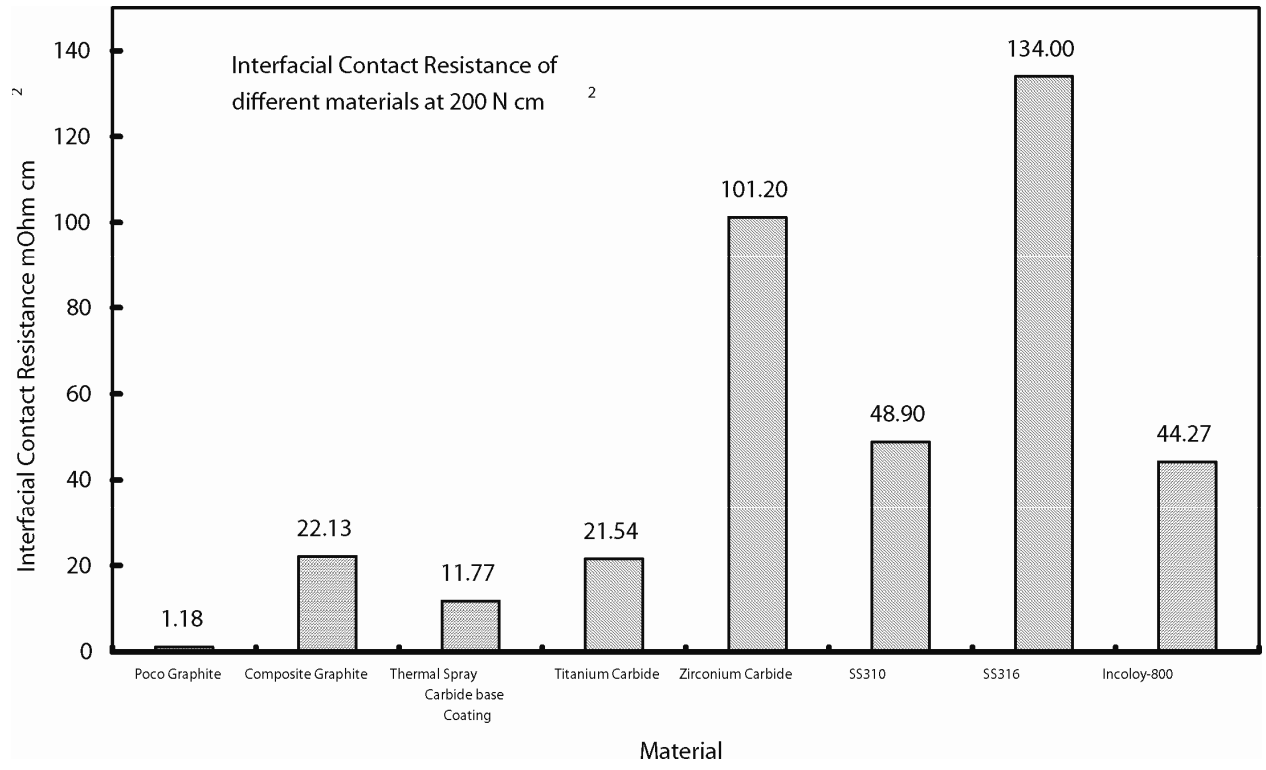


Figure 4 Potentiodynamic polarisation curve of carbide base materials in a deaerated $0.5 \mathrm{M}$ $\mathrm{H}_{2} \mathrm{SO}_{4}+200 \mathrm{ppm} \mathrm{HF}$ at room temperature

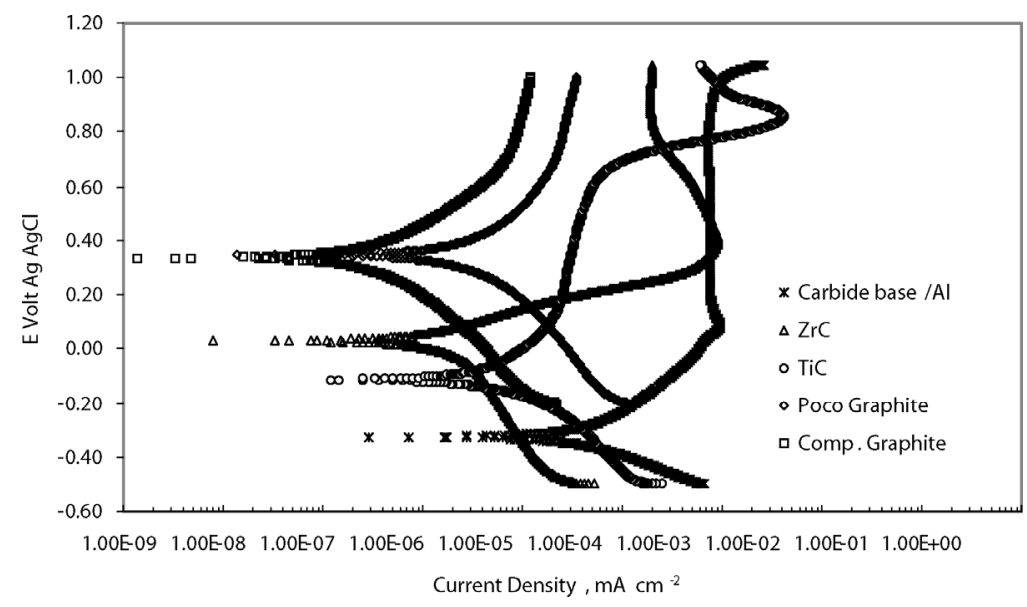

Figure 5 Potentiodynamic polarisation curve of different bipolar material in a deaerated $0.5 \mathrm{M} \mathrm{H}_{2} \mathrm{SO}_{4}+200 \mathrm{ppm} \mathrm{HF}$ at room temperature

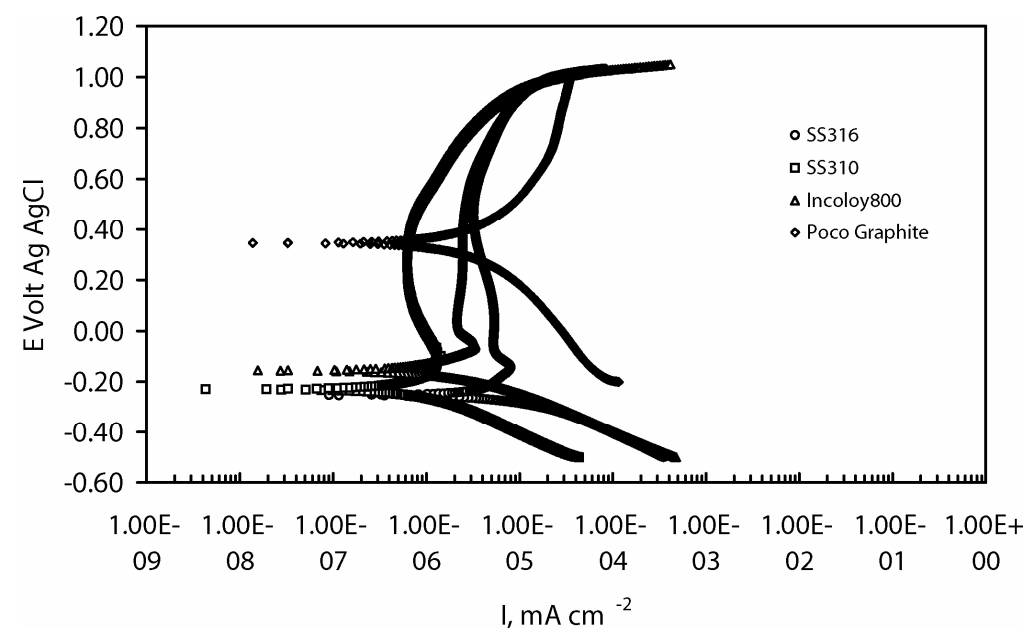

\subsection{Bipolar plate cost analysis}

In our current work, we are attempting to develop a corrosion resistant bipolar plate for the proton exchange membrane fuel cell. An aluminum bipolar plate substrate has been chosen as the base metal due to its low cost, ease of manufacture into stampable bipolar plates and its light weight. Our approach to obtaining a lower cost, smaller and lighter weight fuel cell stack is to coat aluminum with a corrosion resistant coating. Aluminum metal is readily corroded in a fuel cell environment due to the acidic nature of the water in the flow channels. In this study, we demonstrate a coating applied to aluminum by a high velocity thermal spray coating. Low corrosion rates were obtained with carbide base coating and low material cost. This is the focus of the present development effort. 
Figure 6 Corrosion current of different bipolar material in a deaerated $0.5 \mathrm{M} \mathrm{H}_{2} \mathrm{SO}_{4}+200 \mathrm{ppm}$ $\mathrm{HF}$ at room temperature

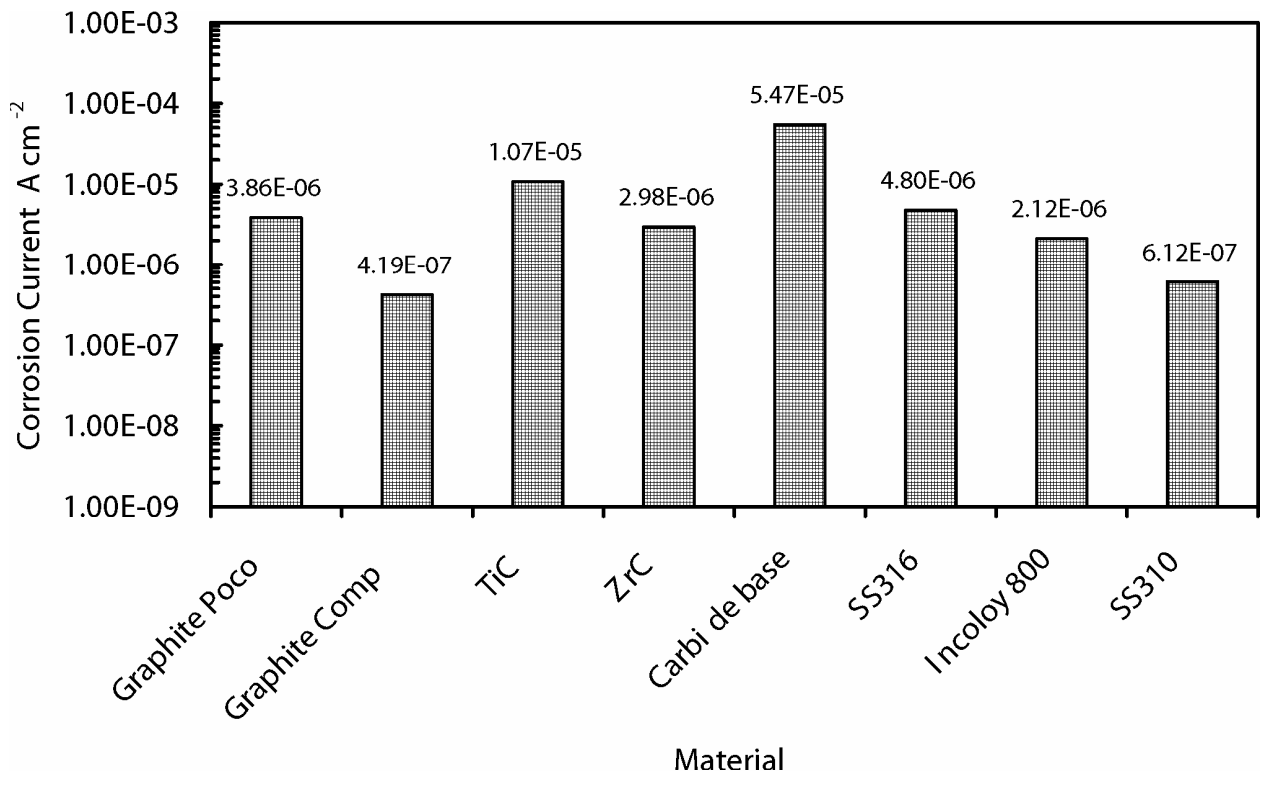

Bipolar plate cost goals have been established by the Department of Energy in conjunction with automotive manufacturers and are currently set at $\$ 10 \mathrm{~kW}^{-1}$ (for material and fabrication cost of the bipolar plate). An assessment of bipolar plates fabricated with graphite, and carbide base thermally-sprayed coated aluminum was conducted in order to determine a cost per kilowatt for the bipolar plate. Table 1. shows the design assumptions for a $1 \mathrm{~kW}$ fuel cell stack and capital cost of both material.

The economical analysis and comparison between graphite composites and Carbide base metallic coating alloy developed by our previous work (Hung, El-Khatib and Tawfik, 2006) and applied on carbide base coating on aluminum bipolar plates showed $22 \%$ savings in hydrogen consumption, based on this results the hydrogen consumption per kilowatt fuel cell stack are shown in Table 2. Considering both running and fixed costs for these two types of plate materials, Table 3 shows a comparison and cost analysis of both materials of a $1 \mathrm{~kW}$ fuel cell stack

The initial cost of metallic bipolar plates is slightly higher comparing to the graphite bipolar plate due to the secondary thermal spray manufacturing process, however, after the first three months of operation and due to savings in hydrogen consumption the total cost of graphite composites begins to exceed the metallic as depicted in Figure 7. 
Table 1 Bipolar design assumption and capital cost of the thermal-sprayed bipolar plate and composite graphite

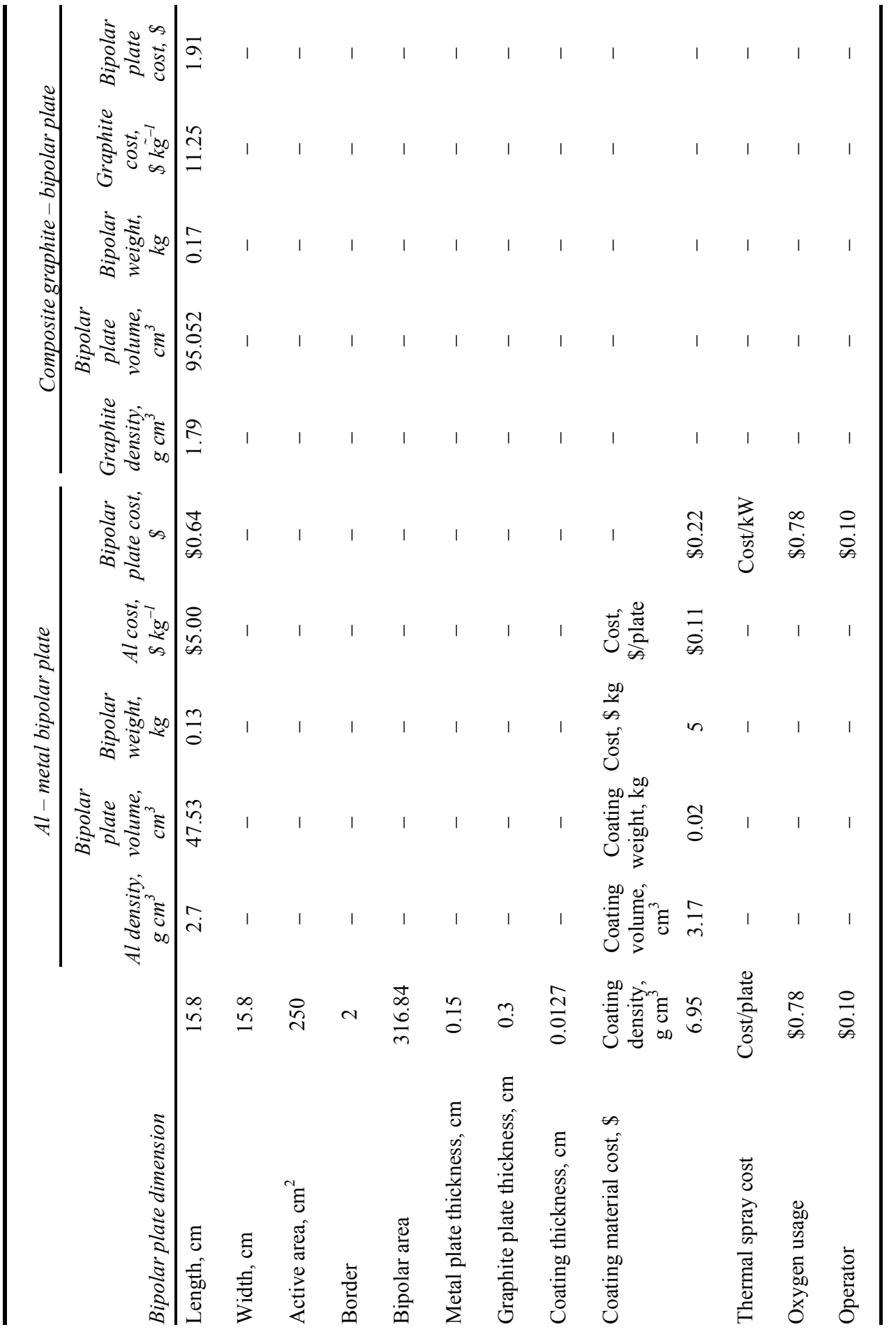


Corrosion and contact resistance measurements

Table 1 Bipolar design assumption and capital cost of the thermal-sprayed bipolar plate and composite graphite (continued)

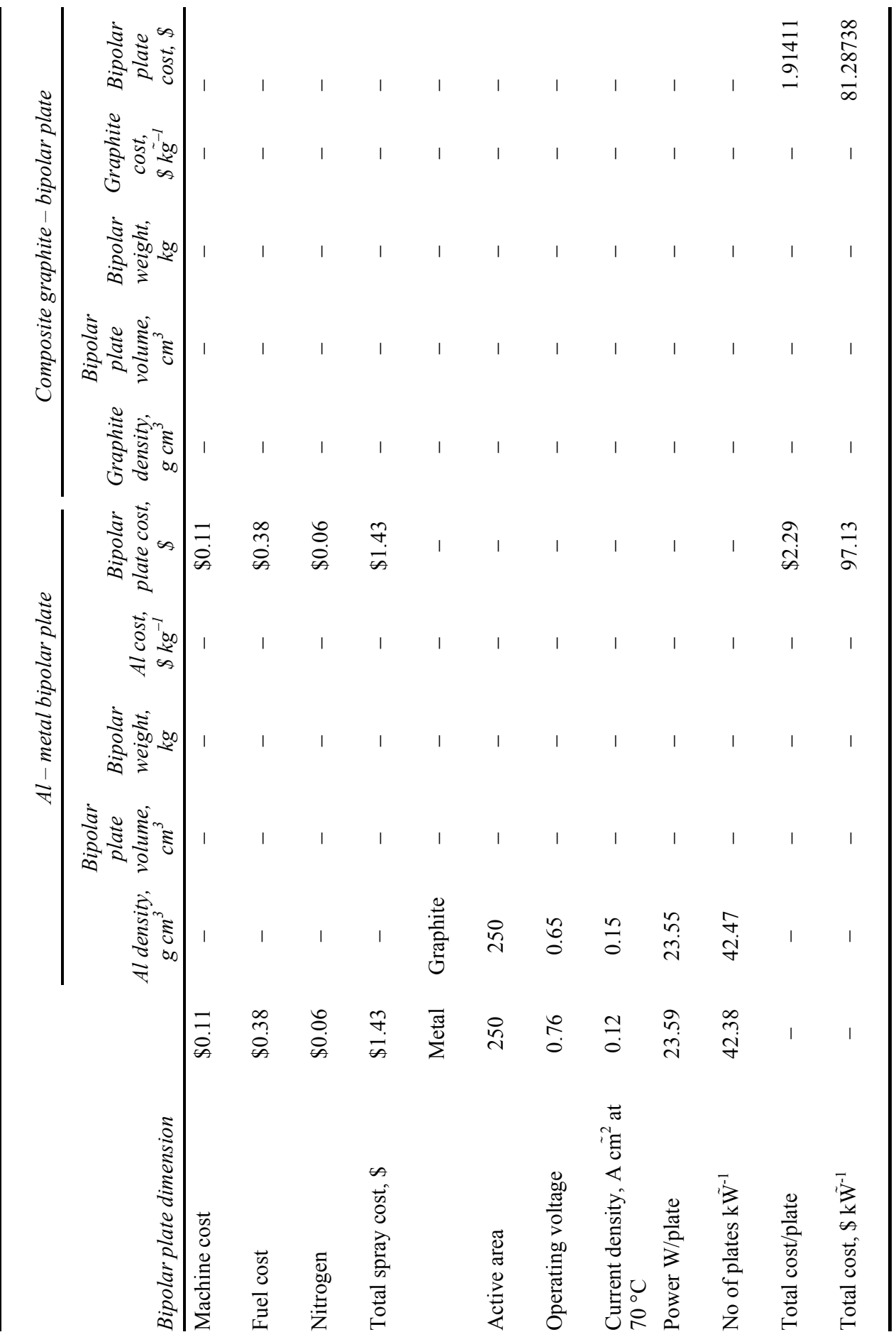


Table 2 Hydrogen consumption for both materials

\begin{tabular}{|c|c|c|}
\hline Item & Carbide base/Al & Composite graphite \\
\hline Cell area, $\mathrm{cm}^{2}$ & 250 & 250 \\
\hline Stack power, $\mathrm{W}$ & 1,000 & 1,000 \\
\hline Current, A & 0.8 & 0.936 \\
\hline Current density $\mathrm{A} \mathrm{cm}^{2}$ & 0.124 & 0.145 \\
\hline Current/plate & 31.00 & 36.27 \\
\hline Voltage/plate & 0.76 & 0.65 \\
\hline $\mathrm{SCCM} / \mathrm{W}$ & 8.811 & 10.96 \\
\hline Power density, $\mathrm{W} \mathrm{cm}^{-2}$ & 0.094 & 0.088 \\
\hline Watt/plate & 23.64 & 23.58 \\
\hline Number of plate/ $1,000 \mathrm{~W}$ & 42.29 & 42.41 \\
\hline $\mathrm{H}_{2}$ consumption $\mathrm{m}^{3} \min ^{-1}$ & 0.0088 & 0.011 \\
\hline Total $\mathrm{H}_{2}$ consumption per $\mathrm{kW}, \mathrm{cm}^{3} \min ^{-1}$ & 8,811 & 10,960 \\
\hline Gas constant $-\mathrm{R}\left(\mathrm{kN} \mathrm{m} \mathrm{kg} \mathrm{k}^{-1}\right)$ & 8.314 & 8.314 \\
\hline Pressure $-\mathrm{p}\left(\mathrm{kN} \mathrm{m}^{2}\right)$ & 101.325 & 101.325 \\
\hline Temperature $-\mathrm{T}(\mathrm{K})$ & 293 & 293 \\
\hline Hydrogen molecular weight & 2 & 2 \\
\hline Hydrogen consumption $\left(\mathrm{kg} \mathrm{min}{ }^{-1}\right)$ & 0.000733 & 0.000912 \\
\hline Hydrogen usage for $1 \mathrm{~kW}$ hour $(\mathrm{kg})$ & 0.04398 & 0.0547 \\
\hline Cost of Hydrogen $\left(\mathrm{kg}^{-1}\right)$ & $\$ 4.30$ & $\$ 4.30$ \\
\hline Cost for $1 \mathrm{~kW}$ hour & $\$ 0.189$ & $\$ 0.235$ \\
\hline
\end{tabular}

Figure 7 Cost comparison between coated aluminum and graphite bipolar plates

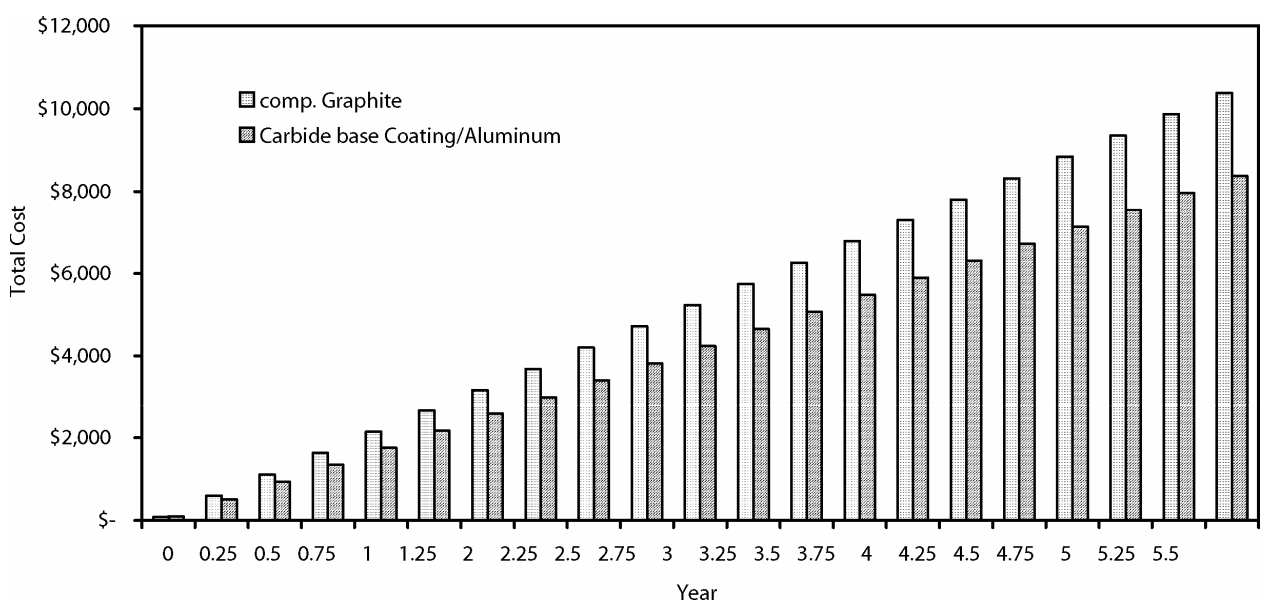


Table 3 Comparison of energy cost generated by treated metal and graphite bipolar plates with the cost of hydrogen $\$ 4.3 \mathrm{~kg}^{-1}$

\begin{tabular}{|c|c|c|c|c|c|c|c|}
\hline & $\begin{array}{c}5 \text { years } \\
\text { projection }\end{array}$ & $\begin{array}{c}\text { Capital } \\
\text { cost, } \$\end{array}$ & $\begin{array}{c}\text { Capital } \\
\text { cost, } \$\end{array}$ & $\begin{array}{c}\text { Hydrogen } \\
\text { cost, } \$\end{array}$ & $\begin{array}{c}\text { Hydrogen } \\
\text { cost, } \$\end{array}$ & $\begin{array}{c}\text { Total } \\
\text { cost, } \$\end{array}$ & $\begin{array}{c}\text { Total } \\
\text { cost, } \$\end{array}$ \\
\hline Year & $\begin{array}{l}\text { (with cost of } \\
\text { hydrogen) }\end{array}$ & $\begin{array}{l}\text { Comp. } \\
\text { graphite }\end{array}$ & $\begin{array}{c}\text { Carbide base } \\
\text { coating/AL }\end{array}$ & $\begin{array}{l}\text { Comp. } \\
\text { graphite }\end{array}$ & $\begin{array}{c}\text { Carbide base } \\
\text { coating/AL }\end{array}$ & $\begin{array}{l}\text { Comp. } \\
\text { graphite }\end{array}$ & $\begin{array}{c}\text { Carbide base } \\
\text { coating } / A L\end{array}$ \\
\hline 0 & 0 & $\$ 81.29$ & $\$ 97.13$ & $\$ 0.235$ & $\$ 0.189$ & $\$ 81.52$ & $\$ 97.324$ \\
\hline 0.25 & 2,190 & - & - & $\$ 515.16$ & $\$ 414.15$ & $\$ 596.45$ & $\$ 511.29$ \\
\hline 0.5 & 4,380 & - & - & $\$ 1,030.32$ & $\$ 828.30$ & $\$ 1,111.61$ & $\$ 925.44$ \\
\hline 0.75 & 6,570 & - & - & $\$ 1,545.48$ & $\$ 1,242.45$ & $\$ 1,626.77$ & $\$ 1,339.59$ \\
\hline 1 & 8,760 & - & - & $\$ 2,060.65$ & $\$ 1,656.60$ & $\$ 2,141.93$ & $\$ 1,753.74$ \\
\hline 1.25 & 10,950 & - & - & $\$ 2,575.81$ & $\$ 2,070.75$ & $\$ 2,657.09$ & $\$ 2,167.89$ \\
\hline 2 & 13,140 & - & - & $\$ 3,090.97$ & $\$ 2,484.90$ & $\$ 3,172.26$ & $\$ 2,582.04$ \\
\hline 2.25 & 15,330 & - & - & $\$ 3,606.13$ & $\$ 2,899.05$ & $\$ 3,687.42$ & $\$ 2,996.19$ \\
\hline 2.5 & 17,520 & - & - & $\$ 4,121.29$ & $\$ 3,313.20$ & $\$ 4,202.58$ & $\$ 3,410.34$ \\
\hline 2.75 & 19,710 & - & - & $\$ 4,636.45$ & $\$ 3,727.35$ & $\$ 4,717.74$ & $\$ 3,824.49$ \\
\hline 3 & 21,900 & - & - & $\$ 5,151.61$ & $\$ 4,141.50$ & $\$ 5,232.90$ & $\$ 4,238.64$ \\
\hline 3.25 & 24,090 & - & - & $\$ 5,666.78$ & $\$ 4,555.65$ & $\$ 5,748.06$ & $\$ 4,652.79$ \\
\hline 3.5 & 26,280 & - & - & $\$ 6,181.94$ & $\$ 4,969.80$ & $\$ 6,263.22$ & $\$ 5,066.94$ \\
\hline 3.75 & 28,470 & - & - & $\$ 6,697.10$ & $\$ 5,383.95$ & $\$ 6,778.39$ & $\$ 5,481.09$ \\
\hline 4 & 30,660 & - & - & $\$ 7,212.26$ & $\$ 5,798.10$ & $\$ 7,293.55$ & $\$ 5,895.24$ \\
\hline 4.25 & 32,850 & - & - & $\$ 7,727.42$ & $\$ 6,212.25$ & $\$ 7,808.71$ & $\$ 6,309.39$ \\
\hline 4.5 & 35,040 & - & - & $\$ 8,242.58$ & $\$ 6,626.40$ & $\$ 8,323.87$ & $\$ 6,723.54$ \\
\hline 4.75 & 37,230 & - & - & $\$ 8,757.74$ & $\$ 7,040.56$ & $\$ 8,839.03$ & $\$ 7,137.69$ \\
\hline 5 & 39,420 & - & - & $\$ 9,272.91$ & $\$ 7,454.71$ & $\$ 9,354.19$ & $\$ 7,551.84$ \\
\hline 5.25 & 41,610 & - & - & $\$ 9,788.07$ & $\$ 7,868.86$ & $\$ 9,869.35$ & $\$ 7,965.99$ \\
\hline 5.5 & 43,800 & - & - & $\$ 10,303.23$ & $\$ 8,283.01$ & $\$ 10,384.52$ & $\$ 8,380.14$ \\
\hline
\end{tabular}

\section{Conclusions}

In simulated PEMFC environments, i.e. $0.5 \mathrm{M} \mathrm{H}_{2} \mathrm{SO}_{4}+200 \mathrm{ppm}$ HF solution, stainless steel 316 showed a high ICR and undergo corrosion in both anode and cathode due to the passive film formation. Moreover, although carbide-based alloy showed an ICR much less than composite graphite, their behaviour was not satisfactory in corrosive acidic medium. The metallic alloy showed a pitting corrosion almost at $1.0 \mathrm{Vsce}$, while the nonmetallic alloy not shows any pitting behaviour with increasing the polarisation potential. Composite graphite and SS310 fulfil the DOE corrosion current target value. The thermal-sprayed carbide base coating showed a cost effective due to the $22 \%$ of hydrogen saving per watt comparing to graphite as bipolar plate. 


\section{References}

Borup, R.L. and Vanderborgh, N.E. (1995) 'Design and testing criteria for bipolar plate material for PEM fuel cell application', Paper presented in the Proceedings of the Material Research Society Symposium, Vol. 393, pp.151-155.

Brady, M.P., Weisbrod, K., Paulauskas, I., Buchanan, R.A., More, K.L., Wang, H., Wilson, M., Garzon, F. and Walker, L.R. (2004) 'Preferential thermal nitridation to form pin-hole free $\mathrm{Cr}$-nitrides to protect proton exchange membrane fuel cell metallic bipolar plates', Scripta Materialia, Vol. 50, pp.1017-1022.

Davies, D.P., Adcock, P.L., Turpin, M. and Rowen, S.J. (2000) 'Bipolar plate materials for solid polymer fuel cells', Journal of Applied Electrochemistry, Vol. 30, pp.101-105.

Gamboa, S.A., Gonzalez-Rodriguez, J.G., Valenzuela, E., Campillo, B., Sebastian, P.J. and Reyes-Rojas, A. (2006) 'Evaluation of the corrosion resistance of Ni-Co-B coatings in simulated PEMFC environment', Electrochimica Acta, Vol. 51, pp.4045-4051.

Hentall, P.L., Lakeman, J.B., Mepsted, G.O., Adcock, P.L. and Moore, J.M. (1999) Journal of Power Sources, Vol. 80, p.235.

Hermann, A., Chaudhuri, T. and Spagnol, P. (2005) 'Bipolar plates for PEM fuel cells: a review', Int. J. Hydrogen Energy, Vol. 30, pp.1297-1302.

Hung, Y., El-Khatib, K.M. and Tawfik, H. (2006) 'Testing and evaluation of aluminum coated bipolar plates of PEM fuel cell operating at $70^{\circ} \mathrm{C}$ ', Journal of Power Sources, Vol. 163, pp.509-513.

Iversen, A.K. (2006) 'Stainless steels in bipolar plates - surface resistive properties of corrosion resistant steel grades during current loads', Corrosion Science, Vol. 48, pp.1036-1058.

Jayaraj, J., Kim, Y.C., Kim, K.B., Seok, H.K. and Fleury, E. (2005) 'Corrosion studies on Fe-based amorphous alloys in simulated PEM fuel cell', Environment Science and Technology of Advanced Materials, Vol. 6, pp.282-289.

Lee, S-J., Huang, C-H. and Chen, Y-P. (2003) 'Investigation of PVD coating on corrosion resistance of metallic bipolar plates in PEM fuel cell', Journal of Materials Processing Technology, Vol. 140, pp.688-693.

Li, M.C., Zeng, C.L., Luo, S.Z., Shen, J.N., Lin, H.C. and Cao, C.N. (2003) 'Electrochemical corrosion characteristics of type 316 stainless steel in simulated anode environment for PEMFC', Electrochimica Acta, Vol. 48, pp.1735-1741.

Li, M., Luo, S., Zeng, C., Shen, J., Lin, H. and Cao, C. (2004) 'Corrosion behavior of TiN coated type 316 stainless steel in simulated PEMFC environments', Corrosion Science, Vol. 46, pp.1369-1380.

Mehta, V. and Cooper, J.S. (2003) 'Review and analysis of PEM fuel cell design and manufacturing', Journal of Power Sources, Vol. 114, pp.32-53.

Nikam, V.V. and Reddy, R.G. (2005) 'Corrosion studies of a copper - beryllium alloy in a simulated polymer electrolyte membrane fuel cell environment', Journal of Power Sources, Vol. 152, pp.146-155.

Steele, B.C.H. and Heinzel, A. (2001) 'Materials for fuel-cell technologies', Nature (London), Vol. 414, p.345.

Tian, R., Sun, J. and Wang, L. (2006) 'Plasma-nitrided austenitic stainless steel 316L as bipolar plate for PEMFC', Int. J. Hydrogen Energy, Vol. 31, pp.1874-1878.

Wang, H. and Turner, J.A. (2004) 'Ferritic stainless steels as bipolar plate material for polymer electrolyte membrane fuel cells', Journal of Power Sources, Vol. 128, pp.193-200.

Wang, H., Sweikart, M.A. and Turner, J.A. (2003) 'Stainless steel as bipolar plate material for polymer electrolyte membrane fuel cells', Journal of Power Sources, Vol. 115, pp.243-251.

Wang, H., Brady, M.P., More, K.L., Meyer, H.M. and Turnera, J.A. (2004) 'Thermally nitrided stainless steels for polymer electrolyte membrane fuel cell bipolar plates Part 2: beneficial modification of passive layer on AISI446', Journal of Power Sources, Vol. 138, pp.79-85. 
Wang, H., Bradyb, M.P., Teetera, G. and Turnera, J.A. (2004) 'Thermally nitrided stainless steels for polymer electrolyte membrane fuel cell bipolar plates Part 1: model $\mathrm{Ni}-50 \mathrm{Cr}$ and austenitic 349TM alloys', Journal of Power Sources, Vol. 138, pp.86-93.

Wind, J., Spah, R., Kaiser, W. and Bohm, G. (2002) 'Metallic bipolar plates for PEM fuel cells', Journal of Power Sources, Vol. 105, pp.256-260.

Woodman, A.S., Anderson, E.B., Jayne, K.D. and Kimble, M.C. (1999) 'Development of corrosion-resistant coatings for fuel cell bipolar plates', Paper presented in the Proceedings of the American Electroplaters and Surface Finishers Society, AESF SUR/FIN '99, Vol. 6, pp.21-24. 